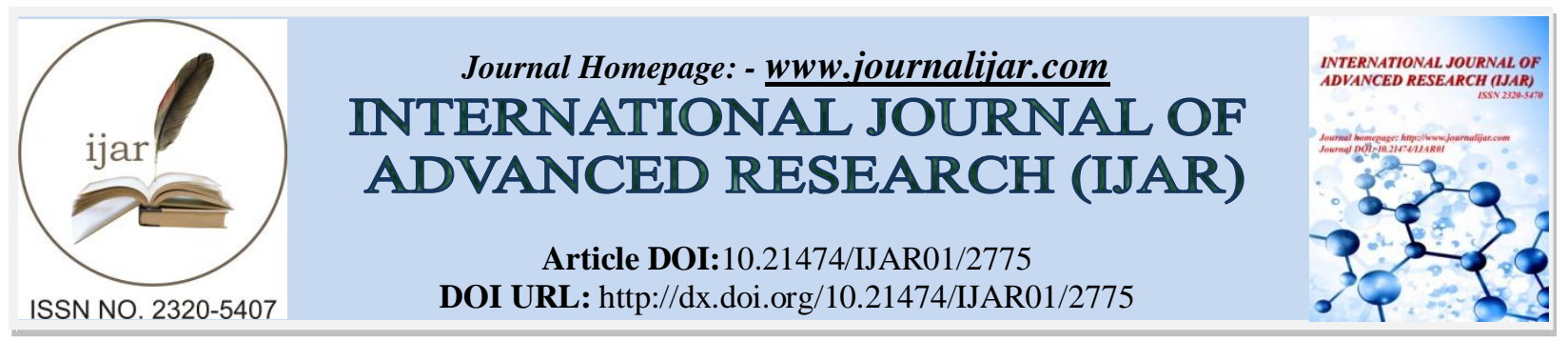

RESEARCH ARTICLE

\title{
INVESTIGATING AN ADOPTION OF SMARTPHONE: A ROAD TO UBIQUITOUS BUSINESS
} MANAGEMENT.

Md Nor Hayati Tahir and Muhammad Ridzuan AbMalek. Universiti Teknikal Malaysia Melaka, Hang Tuah Jaya 76100 Durian Tunggal, Melaka, Malaysia

\section{Manuscript Info}

\section{Manuscript History}

Received: 15 November 2016

Final Accepted: 17 December 2016

Published: January 2017

\section{Key words:-}

Ubiquitous business management, Adoption of smartphone, Organization and business, Diffusion of innovation

\section{Abstract}

Telecommunication technology through smartphones currently provides many benefits and convenience to users. However, not all users are optimizing their smartphones. Currently, there are minimal knowledge of the reasons that entrepreneurs adopted and used smartphones to manage the organization and business. For this purpose, the operational framework applied to this research was adapted from Unified theory of Acceptance and Use of Technology. This quantitative approach research through questionnaires examined104respondents' perception on social influence, facilitating conditions, performance expectancy, effort expectancy,the importanceof adopting and use of smartphones within entrepreneurs for managing business. The contribution of this research revealedthe significant of smartphone usage for business management. The outcomes of this investigation indicated that there was no significant social influence toward entrepreneurs to use smartphone for managing business. Overall, entrepreneurs believed that smartphone waseasy to use and managing business using smartphone can help them increase their performance. This contributed to an increase in their intention to use them. However, the findings showed that the smartphone usage for business management by entrepreneurs is low. Regarding the limitations, these happened because of finance and time factor. To overcome the limitations, this research recommends further studies that apply qualitative research.

Copy Right, IJAR, 2016. All rights reserved.

\section{Introduction:-}

The success and importance of smartphone, especially for business users have very important implication in business management. The Internet has already profoundly changed the way entrepreneurs acquire information about business, managing their company and interact with others, and smartphone plays a large part in this process. The development of the mobile operating systems and software applications has impact on the usage and consumption to manage business.

Smartphone is a phone with an integrated computer feature that can perform more compare to standard phones. According to the Malaysian Communication and Multimedia Commission (2014), the number of smartphone user in Malaysia was $53.4 \%$ from 30,387,862 populations in 2014. The most popular operating system that used in Malaysia is Android (53\%), iOS (23\%) and Windows (10\%). Today, smartphone not only for communication, it also use for 
browsing, social networking, entertainment, and others. The smartphone is a phone that provides more functions and applications than standard phones. The arrival of smartphones has impacted not only to how people communicate but also to business, entertainment and journalism (The Denver Post, 2012).

The advancement of ubiquitous business management will accelerate the productivity of managing business. In order to survive, companies must quickly recognize these various changes that have a major impact on their business and react with the client in a timely manner. Utilizing the existing telecommunication technology, smartphone, it will increase the effectiveness and productivity of an organization. Using smartphone can offer flexibility that will always allow managing companies ubiquitously. According to SME Cloud Malaysia (2015), 91\% of SMEs don't optimize their smartphone for business management. The most common application like telephone, SMS and in the meantime camera functionalities are widely used. This research recognizes the importance of smartphones for managing business. For this, an aim of this paper is to determine and examine the effect of smartphone adoption for business management by applying Unified Theory of Acceptance and Use of Technology (UTAUT).

\section{Small and Medium Enterprise (SME):-}

The main criterions that predominate to define SMEs are the number of employees, turnover and the balance total (Burns, 2001). For example, the European Union (EU) define an SME as enterprises that employ no more than 250 employees, a maximum annual turnover of 40 million Euros and a maximum annual balance sheet total of 27 million Euros (Levy et al., 2003). The few other defining characteristics of SMEs are: (a) Independent ownership and operations, (b) Close control by owners/managers who contribute most, if not all the operating capital and (c) Principal decision-making by the owners/managers (ABS, 2001).

SMEs are very large heterogeneous group of businesses usually operating, among others in the service, trade, agriculture, and manufacturing sectors. According to Ritchie and Brindley (2005), SMEs are significant because of their entrepreneurial spirit and adaptive capabilities. More importantly, SMEs are recognized for being the driver of economic growth and innovation that are crucial for fostering competitiveness (Levy et al., 2003). Their knowledge allows them to innovate on the product or process, which helps them form a competitive advantage to generate more profits (Loh and Koh 2004).

\section{Smartphone:-}

Cassavoy (2012) defined smartphone as a device that enables the user to make telephone call and at the same time has some features that allow the user to do some activities that in the past was not possible unless using a computer or a personal digital assistant (PDA), such as sending and receiving e-mails and amending an office document.

The important things that distinguished smartphone from cell phones are the feature. The operating system allows the smartphone to run its applications such as iPhone runs iOS, other kind of handsets runs Google's Android operating system such as Samsung and Lenovo, and some other runs Microsoft's Windows Phone. Cui and Roto (2008) found that the main use of smartphones was task-oriented with goals of information seeking, communications, online transactions, and managing personal information.

\section{Application of UTAUT:-}

Adoption and use are imperative in this research. The main theories applied in adoption studies are the Diffusion of Innovation (DOI) theory (Rogers, 2003); Unified Theory for the Acceptance and Use of Technology (UTAUT) (Venkatesh et al., 2012, 2003a) and Technology Acceptance Model (TAM) (Davis, 1989). It was found that TAM is the most popular, followed by UTAUT. For instance, DOI and TAM were combined to explain the adoption of smartphones in a logistic industry (Chen et al., 2009). However, UTAUT are preference within the perspective of adoption and use in this research.

The operational framework involvedindependent variables constructs include social influence, facilitating conditions, performance expectancy and effort expectancy that are drawn from UTAUT as shown in Figure 1. Theory also revealed that all the factors that affect user behavioral intention (Venkatesh, 2012). Finally, the mediating variable behavioral intention is influenced by the smartphone usage. Usage measured by the features of a smartphone, which are e-mailing, browsing, using social media, taking a photo and playing games. 


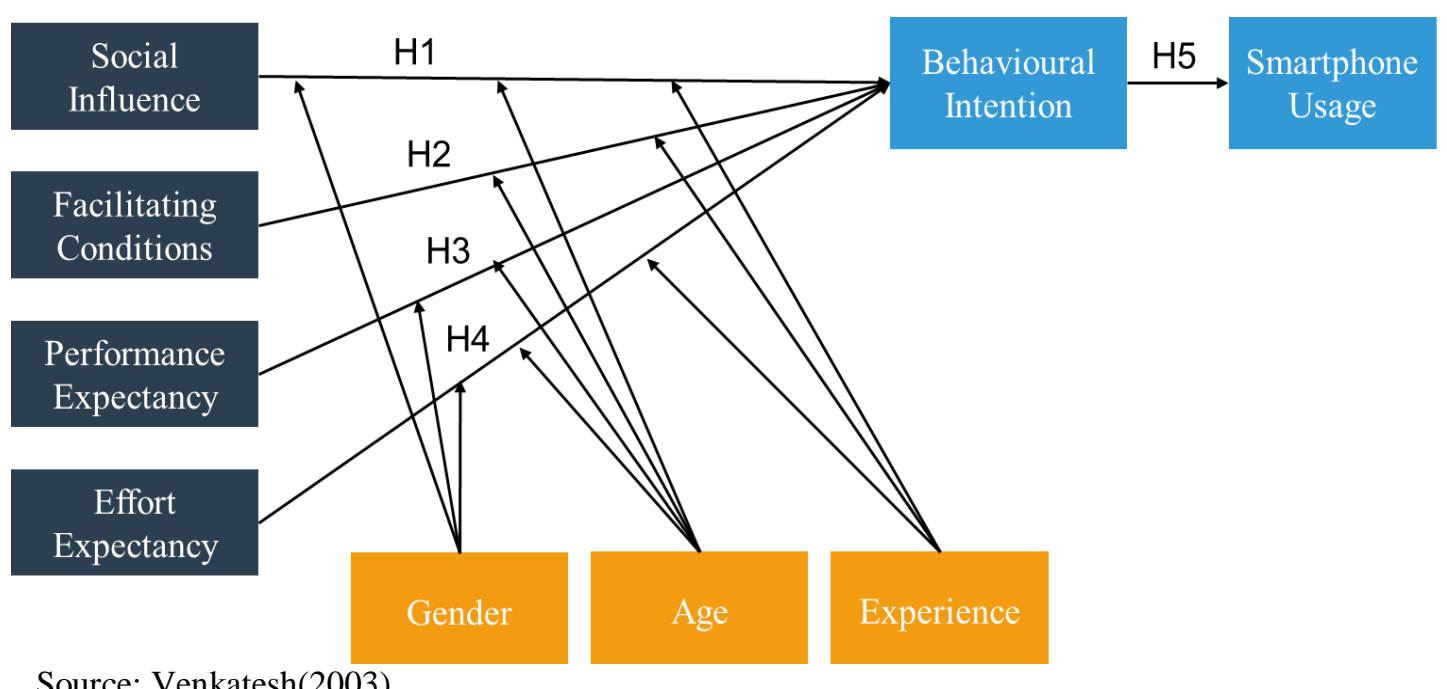

Figure 1:- Operational Framework.

\section{Methodology:-}

The UTAUT model integrates four core determinants, social influence, facilitating conditions, performance expectancy, and effort expectancy significantly predicts intention suggested by Venkatesh et al. (2003). The UTAUT model is well suited to the context of this study. Based on these observations, the hypotheses of this study are:

- Hypothesis 1: Social Influence has an influence on the behavioural intention moderated by gender, age and experience.

- Hypothesis 2: Facilitating Condition has an influence on the behavioural intention moderated by gender, age and experience.

- Hypothesis 3: Facilitating Condition has an influence on the behavioural intention moderated by gender, age and experience.

- Hypothesis 4: Effort Expectancy has an influence on the behavioural intention moderated by gender, age and experience.

- Hypothesis 5: Behavioural intention has an influence on the smartphone usage.

The questionnaire utilized in this research consisted of 3 sections meantto examine the demographics and background of respondents, questions related to independent variables and mediating variablesnamely the social influence, facilitating condition, performance expectancy, effort expectancy and behavioural intention, and questions to seek the smartphone usage as the dependent variable of this study. The questionnaires applied the Likert scale 1 to 5 except the demographic section.

The survey questionnaire was distributed among the SMEs in Malacca, Malaysia. The population was 72,806 comprises of enterprises registered with the Companies Commission of Malaysia (SSM) in Malacca, Malaysia. Krejcie and Morgon (1970) suggested the number of sample must depend on the number of population. From the population, the respondents targeted were 381 samples. This studyapplied simple random sampling where every single element in the population has a known and equal chance of being selected as a member of the sample.

Given the nature of the research topic, it is most suitable to employ both primary and secondary data collection method. Correlation analysis and regression analysis were applied using the Statistics Package for Social Science (SPSS) Version 20.The validity and reliability of the primary data was ascertained before further analysis of the data been computed.Pilot test were carried out involved 3 academicians, 5 students and 2 people at large adopting smartphone.

\section{Result:-}

Data analyses were done after the process of cleaning up the data had been performed. From 600 questionnaires distributed only 104 respondents replied. 


\section{Demographically:-}

The respondents represented by 46 males and 58 females. In term of age, 58.7\% represent $21-30$ years old, $22.1 \%$ represent $31-40$ years old, $14.4 \%$ represent $41-50$ years old, and 51 years old and above is the lowest at $4.8 \%$. In term of race, majorities were Malay $(74 \%)$ compared to Chinese, Indian and others. In term of position, $12.5 \%$ were owners, $10.6 \%$ were managers, $12.5 \%$ were executives, $8.7 \%$ were supervisors, $23.1 \%$ were administrationstaff, $28.8 \%$ were secretary/clerk and $3.8 \%$ were other positions. In term of monthly income, with more than half of the responses earn RM 3,000 and above in a month. All the respondentswere smartphone user but only 55.8\% use their smartphone for managing business. Approximately $42.3 \%$ of the respondentshad experience using smartphone more than 6 years.

Total of 26 questions were used in the research. Reliability analysis showed that the Cronbach's alpha for overall variables was 0.943 indicates that very high and good reliable research.

\section{Correlation analysis:-}

Bivariate correlation was conducted to examine the interrelationships among the variables in this study. There were six variables investigated to understand the adoption of smartphone usage for managing business. As shown in Table 1 , the mediator variable in this study (behavioural intention) was significantly and positively correlated with all four independent variables, namely social influence $(\mathrm{r}=.741, \mathrm{p}=.000)$, facilitating condition $(\mathrm{r}=.803, \mathrm{p}=.000)$, performance expectancy $(r=.790, p=.000)$, and the highest correlate was effort expectancy $(r=.860, p=.000)$.

Despite that, the independent variables namely theperformance expectancy $(\mathrm{r}=.413, \mathrm{p}=.000)$, effort expectancy $(\mathrm{r}=.452, \mathrm{p}=.000)$, and the mediating behavioural intention $(\mathrm{r}=.512, \mathrm{p}=.000)$ were significantly and moderately correlated to the smartphone usage. Nevertheless, social influence $(\mathrm{r}=.293, \mathrm{p}=.003)$ and facilitating condition $(\mathrm{r}=$ $.402, \mathrm{p}=.000)$ were significantly and weakly correlated.

Table 1:0- Correlation Analysis for All Variables

\begin{tabular}{|l|l|l|l|l|l|l|}
\hline Variables & SC & FC & PE & EE & BI & SU \\
\hline Social Influence & 1 & & & & & \\
\hline Facilitating Condition & $.749^{* *}$ & 1 & & & & \\
\hline Performance Expectancy & $.761^{* *}$ & $.743^{* *}$ & 1 & & & \\
\hline Effort Expectancy & $.670^{* *}$ & $.779^{* *}$ & $.743^{* *}$ & 1 & & \\
\hline Behavioural Intention & $.741^{* *}$ & $.803^{* *}$ & $.790^{* *}$ & $.860^{* *}$ & 1 & \\
\hline Smartphone Usage & $.293^{* *}$ & $.402^{* *}$ & $.413^{* *}$ & $.452^{* *}$ & $.512^{* *}$ & 1 \\
\hline
\end{tabular}

Notes: Independent Variables: Social Influence, Facilitating Condition, PerformanceExpectancy, Effort Expectancy. Mediating Variable: Behavioural Intention. Dependent Variable: Smartphone Usage.

**. Correlation is significant at the 0.01 level (2-tailed)

\section{Multiple regression analysis:-}

Table 2 shows the model summary of independent variables as predictors. It suggested two modelswhere Model 1 was independent variables to mediating variable and Model 2 was independent variables to mediating variables includes moderating variables. Table 2 shows that $\mathrm{R}$ square value for Model 1 was 0.815 , which means that $81.5 \%$ of independent variables influence the behavioural intention. However, R square for Model 2 after considering the moderator had slightly increased which was $0.818(81.8 \%)$. It shows that $0.3 \%$ increasing when gender, age and experience moderated the social influence, facilitating condition, performance expectancy, and effort expectancy. This result shows the consistency of previous study which was all four independent variables have huge contribution when measuring behavioural intention on smartphone adoption.

Table 2:- Model Summary of Independent Variables.

\begin{tabular}{|c|l|l|l|l|}
\hline Model & R & R Square & Adjusted R Square & Std. Error of the Estimate \\
\hline 1 & $0.903^{\mathrm{a}}$ & 0.815 & 0.807 & 0.94915 \\
\hline 2 & $0.904^{\mathrm{b}}$ & 0.818 & 0.804 & 0.95644 \\
\hline
\end{tabular}

Notes:

Predictors: (Constant), Effort Expectancy, Social Influence, Performance Expectancy, Facilitating Condition

Predictors: (Constant), Effort Expectancy, Social Influence, Performance Expectancy, Facilitating Condition, Gender, Age, Experience 
Table 3 shows the contribution of behavioural intention as mediator towards smartphone usage. The value of $\mathrm{R}$ square presented 0.262 of predictors, which was contributed $26.2 \%$ towards dependent variable.

Table 3:- Model Summary of Mediating Variables

\begin{tabular}{|l|l|l|l|l|}
\hline Dependent Variable & R & R Square & Adjusted R Square & Std. Error of the Estimate \\
\hline Smartphone Usage & $0.512^{\mathrm{a}}$ & 0.262 & 0.255 & 4.49596 \\
\hline
\end{tabular}

Notes:a. Predictors: (Constant), Behavioural Intention

\section{Anova Analysis:-}

Following to multiple regression, ANOVA was run simultaneously to check the F-test to compare the means of the groups and whether there is a significant difference in strength of independent variable. Table 4 shows the significance level of the multiple regression analysis (MRA). The result of dependent variable show ( $\mathrm{F}=61.456$, $\mathrm{p}=.000)$ for behavioural intention after considering the moderator and $(\mathrm{F}=36.200, \mathrm{p}=.000)$ for smartphone usage where behavioural intention as predictors. This means that the probability of these accruing by chance was less than 0.05 means a significant relationship present between independent variables and dependent variable. In addition, thereis also significant relationship when independent variables and dependent variable afterconsidering the moderating variables. It can be seen that the regression model is a fit to the data.

Table 4:-Anova.

\begin{tabular}{|c|c|c|c|c|c|c|}
\hline $\begin{array}{c}\text { Dependent } \\
\text { Variable }\end{array}$ & & $\begin{array}{l}\text { Sum of } \\
\text { Squares }\end{array}$ & $\mathrm{df}$ & $\begin{array}{l}\text { Mean } \\
\text { Square }\end{array}$ & $\mathrm{F}$ & Sig. \\
\hline \multirow{3}{*}{$\begin{array}{c}\text { Behavioural } \\
\text { Intention }\end{array}$} & Regression & 393.528 & 7 & 56.218 & 61.456 & $0.000^{\mathrm{a}}$ \\
\hline & Residual & 87.818 & 99 & 0.915 & & \\
\hline & Total & 481.346 & 103 & & & \\
\hline \multirow{3}{*}{$\begin{array}{c}\text { Smartphone } \\
\text { Usage }\end{array}$} & Regression & 731.738 & 1 & 731.738 & 36.200 & $0.000^{b}$ \\
\hline & Residual & 2061.791 & 102 & 20.214 & & \\
\hline & Total & 2793.529 & 103 & & & \\
\hline
\end{tabular}

Notes:

Predictors: (Constant), Effort Expectancy, Social Influence, PerformanceExpectancy, Facilitating Condition, Gender, Age, ExperiencePredictors: (Constant), Behavioural Intention

\section{Hypotheses:-}

The study sought to investigate the effects of social influence, facilitating condition, performance expectancy, and effort expectancy on entrepreneurs' behavioural intention, which in turn, influences smartphone usage to manage business. In order to test these hypotheses, a linear multiple regression analysis method was conducted to examine the effect of these predictors on mediator variable.Table 5 summarized the hypothesis findings.

Table 5:- Result of Hypotheses Testing.

\begin{tabular}{|c|c|c|}
\hline No. & Hypotheses & Result \\
\hline 1 & Social Influence $\geq$ Behavioural Intention & Not Supported \\
\hline 2 & Facilitating Condition $\geq$ Behavioural Intention & Supported \\
\hline 3 & Performance Expectancy $\geq$ Behavioural Intention & Supported \\
\hline 4 & Effort Expectancy $\geq$ Behavioural Intention & Supported \\
\hline 5 & Behavioural Intention $\geq$ Smartphone Usage & Supported \\
\hline
\end{tabular}

$\mathbf{H}_{1}$ : Influence between social influence to behavioural intention moderated by gender, age and experience. The result of regression analysis shows that this construct yielded no significant and positive effect on behavioural intention on using smartphone for business management $(\beta=.133, t=1.804, p=0.74)$. Therefore, there was no evidence to reject $\mathrm{H}_{0}$.

$\mathbf{H}_{2}$ : Influence between facilitating condition to behavioural intention moderated by gender, age and experience. The result of regression analysis shows that this construct yielded significant and positive effect on behavioural intention on using smartphone for business management $(\beta=.183, \mathrm{t}=2.280, \mathrm{p}=0.25)$. Therefore, $\mathrm{H}_{2}$ was fully supported 
$\mathbf{H}_{3}$ : Influence between performance expectancy to behavioural intention moderated by gender, age and experience. The result of regression analysis shows that this construct yielded significant and positive effect on behavioural intention on using smartphone for business management $(\beta=.192, t=2.475, p=0.15)$. Therefore, $H_{3}$ was fully supported.

$\mathbf{H}_{4}$ : Influence between performance expectancy to behavioural intention moderated by gender, age and experience. The result of regression analysis shows that this construct yielded significant and positive effect on behavioural intention on using smartphone for business management $(\beta=.486, t=6.479, p=0.00)$. Therefore, $\mathrm{H}_{4}$ was fully supported

$\mathbf{H}_{5}$ : Influence between behavioural intentions to smartphone usage. The result of regression analysis shows that this construct yielded significant and positive effect on using smartphone for business management $(\beta=.512, \mathrm{t}=6.017$, $\mathrm{p}=0.00)$. Therefore, $\mathrm{H}_{5}$ was fully supported.

Effect of Demographic as Moderated Variables:-

The results of the moderated variables as shown in Table 6, disclosed that all the moderator as not significant to the independent variables $(\mathrm{p}>0.05)$.

Table 6:- Exclude Variables.

\begin{tabular}{|c|l|l|l|l|l|l|}
\hline \multicolumn{2}{|c|}{ Model } & Beta In & t & Sig. & $\begin{array}{l}\text { Partial } \\
\text { Correlation }\end{array}$ & Collinearity Statistics \\
\cline { 5 - 7 } & & & & & Tolerance \\
\hline & Gender & $0.049^{\mathrm{b}}$ & 1.095 & 0.276 & 0.110 & 0.934 \\
& Age & $0.004^{\mathrm{b}}$ & 0.087 & 0.931 & 0.009 & 0.755 \\
& Experience & $0.030^{\mathrm{b}}$ & 0.642 & 0.522 & 0.065 & 0.865 \\
\hline
\end{tabular}

Notes: a. Dependent Variable: Behavioural Intention

b. Predictors in the Model: (Constant), Effort Expectancy, Social Influence, Performance Expectancy, Facilitating Condition

This means that the effect of social influence, facilitating conditions, performance expectancy, and effort expectancy not contributed by gender, age, and experience. The implications of these results are gender, age, and experience of individuals have no influence on adopting smartphone for business management.

\section{Discussion:-}

The total respondents were 104 entrepreneurs who involved in business in the area of Malacca, Malaysia. Form the analysis, majority of the respondents agreedthat social influence, facilitating condition, performance expectancy, effort expectancy, and behavioural intention influence them to use smartphone for managing business. However, this study find out the respondents utilize their smartphone to managing the business still low.

\section{Smartphone Usage towards Business Management:-}

It can be seen that there are several aspects of smartphone technologies that can be explored. Therefore this research on smartphone and entrepreneurs should provide a contribution that focuses not only on the device, but also the use aspect including the frequency of use for business activities. This research provides the relationship between the factors that influenced the behaviour intention that effect the usage of smartphone for managing business.

In terms of the use of smartphone, making phone calls, texting, e-mailing, general Internet browsing, downloading application, and online social networking proved to be the most popular cases among respondents. Previous research has shown that e-mail, an application offered by all smartphones is identified as an important feature (Kim, 2011). To achieve ubiquitous business management, one of the factors should be utilizing their smartphone for managing the business. However, the result showed that only small number of user used smartphone for managing business using Voice over IP and business management application where the meanswere 2.95 and 2.76. The percentage of respondents using business management application constantly low (18.3\%), whereas $30.8 \%$ of respondents never used it before.

\section{Social Influence and Behavioural Intention:-}

Findings show a social influence is not supported in this research.It was suggested that respondents would not be influenced by their friends and family to use smartphone for managing business even though smartphone is a 
necessity of today. Demographically, most of respondents are smartphone user and almost half of them used it for more than 6 years.

\section{Facilitating Condition and Behavioural Intention:-}

This research findings confirmed that entrepreneurs need to have time, money, knowledge, fit well and solving problem of using quickly in order to adopt smartphones for managing business. For a new adopter, familiarization of the smartphone and the application will be motivated by the performance expectancy.

\section{Performance Expectancy and Behavioural Intention:-}

In this study, the hypothesis was supported because entrepreneurs aware that smartphone can help them to increase their productivity and performance, to become a ubiquitous business management.

\section{Effort Expectancy and Behavioural Intention:-}

Effort Expectancy is related to the ease of use of smartphones for entrepreneurs for managing business. This hypothesis can lead to an understanding for smartphone developers and application developers that they should attempt to develop devices and technologies for entrepreneurs that are user friendly.

\section{Behavioural Intention and Smartphone Usage/Actual behaviour:-}

The effect of behavioural intention to smartphone usage can be identified with simple regression analysis. This study found there have positive relationship between behavioural intentions to smartphone usage.

There are limitation to the result such as lower response rate may have affected the analysis of cultural differences in the intention to use a smartphone. The overall response rate for the survey should be 30\% to 60\% (Fowler, 2009). The lacking of top level management as the respondents limits the generalizability of the results (Nenty, 2009). The third limitation was that $44.2 \%$ of the research participants not used their smartphones for managing business. This limits the generalization of the results those who do not use their smartphone for managing business, it is just a mere perception of individual.

\section{Conclusion:-}

This research focused on a trend that are currently occurring in society and in the technology sectors - an entrepreneurs and smartphone technology. Smartphones provide advanced telecommunication and mobile phone functions, which can provide seamless benefits to the users and to work productively that can contribute to better quality of life. From the statistical analysis it was found that many individuals are connected globally through their mobile phones. However, those entrepreneurs are using the smartphones at a basic level only for making a phone call, SMS, email, and browsing. Entrepreneurs were also likely to use their smartphones for online social networking and downloading application, but surprisingly more than half of them did not use smartphones for business management purposes. It can be concluded that smartphone adoption can offer critical mass adoption but the gap is still exists within entrepreneurs used towards business management.

\section{Acknowledgement:-}

Thank you to UniversitiTeknikal Malaysia Melaka for providing the researchersome facilities to support this research.

\section{Reference:-}

1. ABS (2001): Small Business in Australia. Australian Bureau of Statistics. Canberra.

2. Burns, P. (2001): Entrepreneurship and Small Business. Hampshire, UK, Palgrave.

3. Chen, J. V., Yen, D. C. and Chen, K. (2009): The Acceptance and Diffusion of the Innovative Smartphone Use: A Case Study of a Delivery Service Company in Logistics:Information \&Management., 46 (4): 241-248.

4. Cui, Y., and Roto, V. (2008): How People Use the Web on Mobile Devices, International World Wide Web Conference 2008, Beijing, China, pp. $905-914$.

5. Davis, F. D. (1989): Perceived Usefulness, Perceived Ease of Use, and User Acceptance of Information Technology, MIS Quarterly, 13 (September): 319 - 340.

6. Fowler, F. J., Jr. (2009): Survey Research Method (4th ed.). Thousand Oaks, CA: Sage.

7. Kim, S. (2011): The Diffusion of the Internet: Trend and Causes. Social Science Research, 40 (2):pp.602-613.

8. Krejcie, R. V \& Morgan, D.W. (1970):Determining sample size for research activities. EducPsycholMeas. 
9. Levy, M., C. Loebbecke, et al. (2003): SMEs, Co-opetition and Knowledge Sharing: the RoleofInformation Systems, European Journal of Information Systems, 12(1): 3-17.

10. Loh, T. C. and S. C. L. Koh (2004):Critical elements for a successful enterprise resource planning implementation in smalland medium-sized enterprises, International Journal of Production Research, 42 (17): $3433-3455$.

11. Malaysian Communications and Multimedia Commission (2015): Hand Phone Users Survey 2014. http://www.skmm.gov.my/Resources/Statistics/Hand-phone-Surveys.aspx, [Accessed:10 November 2015]

12. Nenty, H. J. (2009): Writing a Quantitative Research Thesis. International Journal of Educational Sciences, $1(1), 19-32$.

13. Ritchie, B. and C. Brindley (2005):ICT adoption by SMEs: Implications for Relationships andManagement." New Technology, Work and Employment 20(3): 205-217.

14. Rogers, E. M. (2003): Diffusion of Innovations. New York: Free Press.

15. Saunders, M., Lewis, P. \&Thornhill, A. (2009): Research Methods for Business Students. London: Pearson Education Limited.

16. SME Cloud Malaysia (2015): http://www.mscmalaysia.my/cloud_sme[Accessed: 28 October 2015]

17. The Denver Post. (2012). Smartphones Boost Economy.http://www.denverpost.com/opinion/ci_21538000/editorial- smartphones- boost-economy, [Accessed: 28 November 2015].

18. Venkatesh, V., Morris, M.G., Davis, G.B., \& Davis, F.D. (2003): User Acceptance of Information Technology: Toward a Unified View. MIS Quarterly.

19. Venkatesh, V. (2012) Technology Acceptance, http://www.vvenkatesh.com/it/organizations/Theoretical_Models.asp[Accessed: 24November 2015]. 